\title{
Konseling Karir dengan Menggunakan Career Information-Processing Model untuk Membantu Career Decision-Making
}

\author{
Fatma Nur Aqmarina, Riana Sahrani, Rahmah Hastuti \\ Universitas Tarumanagara, Jakarta \\ e-mail : pinksyauqi@gmail.com
}

\begin{abstract}
Having graduated from senior high school, most of high school students continue their education to university level. This research aimed to find effectiveness of career counseling by using career information-processing model to assist career decision-making for students of MAN Y Jakarta. The career information-processing model emphasizes the mind and memory in the process of problem solving and career decision-making (Henderson, 2009). This research used quasiexperiment one group pre-test post-test design involving 7 participants who previously experienced the obstacle in career decision-making. The career counseling intervention was implemented in 9 sessions. Based on paired sample t-test $(t=8.576, p<.01)$, result showed that career counseling intervention was effective to assist career counseling for students of MAN $Y$ Jakarta. Thus, intervention in this study could serve as a model of intervention to assist students in career decision-making.
\end{abstract}

Keywords: career, career counseling, career information-processing model, career decision-making

\begin{abstract}
Abstrak
Setelah lulus pendidikan menengah atas, umumnya siswa madrasah aliyah (MA) melanjutkan pendidikannya ke tingkat perguruan tinggi. Penelitian ini bertujuan menguji efektivitas career counseling dengan pendekatan career information-processing model dalam membantu career decision-making pada siswa MAN Y Jakarta. Dalam pendekatan career information-processing model menekankan pada pikiran dan memori dalam proses menyelesaikan masalah dan mengambil keputusan karir (Henderson, 2009). Desain penelitian ini adalah kuasi eksperimen menggunakan one group pre-test post-test dengan jumlah partisipan 7 orang yang diketahui sebelumnya mengalami hambatan dalam mengambil keputusan jurusan kuliah. Intervensi career counseling dilakukan dalam 9 sesi. Berdasarkan hasil paired sample t-test $(\mathrm{t}=8.576$ dan $\mathrm{p}<.01)$, intervensi counseling career yang dilakukan efektif dalam membantu career decision-making pada siswa MAN Y Jakarta. Dengan demikian, intervensi dalam penelitian ini dapat menjadi model intervensi untuk membantu siswa dalam career decision-making.
\end{abstract}

Kata Kunci: karir, konseling karir, model proses informasi karir, pengambilan keputusan karir

\section{Pendahuluan}

Remaja yang berada pada rentang usia 16-18 tahun adalah individu-individu yang sedang menempuh jenjang pendidikan menengah. Berdasarkan satuan pendidikan penyelenggara, pendidikan menengah terdiri dari sekolah menengah atas (SMA), madrasah aliyah (MA) dan sekolah menengah kejuruan (SMK). Pada penelitian ini subyek penelitiannya adalah siswa remaja Madrasah Aliyah (disingkat MA). Madrasah Aliyah adalah jenjang pendidikan menengah pada pendidikan formal di Indonesia, setara dengan sekolah menengah atas, yang pengelolaannya dilakukan oleh Kementerian Agama. Pendidikan Madrasah Aliyah ditempuh dalam waktu tiga tahun, mulai dari kelas 10 sampai kelas 12 .

Kurikulum madrasah aliyah (MA) sama dengan kurikulum sekolah menengah atas (SMA), hanya saja pada MA terdapat porsi lebih banyak mengenai pendidikan agama Islam. Pelajar MA umumnya berusia 16-18 tahun. Adapun tujuan MA sama dengan SMA yaitu untuk mengantarkan siswa memasuki perguruan tinggi umum maupun perguruan tinggi Islam. Sebagian siswa remaja dengan 
mudah memilih karirnya, tetapi ada sebagian remaja lainnya yang mengalami kesulitan dalam memilih karir dan mengabaikannya (Gati, Krausz, dan Osipow dikutip dalam Gati dan Levin, 2014). Remaja yang kesulitan dalam mengambil keputusan karir disebabkan oleh beberapa faktor diantaranya kurangnya persiapan, kurangnya informasi dan kesulitan dalam penggunaan informasi (Gati dan Levin, 2014).

Berdasarkan data studi pendahuluan yang dihimpun peneliti pada bulan Oktober 2015 di Madrasah Aliyah Negeri Y Jakarta, bahwa 91 siswa kelas 12 masih bingung mengambil jurusan kuliah $(61,07 \%)$, sisanya 58 siswa sudah memiliki pilihan jurusan kuliah $(38,93 \%)$. Sedangkan pada bulan Januari 2016 siswa kelas 12 dituntut mengambil jurusan tertentu di perguruan tinggi, karena pada bulan Januari sudah mulai dibuka pendaftaran masuk perguruan tinggi melalui seleksi nasional masuk perguruan tinggi negeri (SNMPTN undangan) dan melalui jalur penelusuran minat dan bakat (PMDK).

Berdasarkan penelitian yang dilakukan oleh Intani dan Surjaningrum (2010), bahwa ada beberapa masalah yang dapat muncul ketika individu merasa salah jurusan saat kuliah antara lain masalah psikologis, akademis dan relasional. Masalah psikologis yang dialami seperti perasaan tertekan, tidak nyaman, marah dan menyesal. Sedangkan masalah akademis yang muncul ketika salah jurusan seperti IPK (indeks prestasi kumulatif) dan nilai rendah, mengulang mata kuliah, perpanjangan masa kuliah, malas belajar, sulit memahami mata kuliah, dan tidak termotivasi dalam belajar. Selain masalah psikologis dan akademik masalah lain yang muncul adalah masalah relasional seperti konflik dengan orang tua.

Oleh sebab itu, peneliti merasa penting membuat sebuah intervensi yang dapat membantu siswa untuk mengatasi hambatan-hambatan dalam membuat keputusan jurusan kuliah. Membuat keputusan karir (career decision-making) merupakan proses kesepakatan antara individu yang membuat keputusan atau dengan keadaan di sekitar (Swanson dan Archiardi dikutip dalam Gati dan Levin, 2014). Keputusan karir berarti keyakinan siswa memilih jurusan pendidikan dan membuat pilihan karir (Osipow, Carney, Winer, Yanico, dan Koschier dikutip dalam Gati dan Levin, 2014). Dari data yang dijelaskan di atas bahwa beberapa diantara kebingungan siswa dalam mengambil keputusan karir dipengaruhi oleh pikiran negatifnya seperti keraguan terhadap pilihannya, merasa banyak saingan untuk masuk perguruan tinggi dan ketakutan nilai akademik yang dimiliki tidak mencukupi untuk pilihan jurusan yang diminati.

Berdasarkan penelitian sebelumnya yang dilakukan oleh Chason, Yowell, Sampson, Lenz, dan Reardon (2013) bahwa pikiran negatif akan berdampak pada tidak berfungsinya kognisi (dysfunctional cognition) individu sehingga akan berdampak negatif pada pengambilan keputusan karir individu. Dysfunctional cognition menyebabkan individu bertingkah laku tidak tepat dalam mengambil keputusan karir seperti menunda pengambilan keputusan, cemas, tergantung kepada orang lain, dan tidak matang dalam mengambil keputusan (Yowell, Peterson, Reardon, Leierer, dan Reed, 2011; Chason, dkk., 2013; Austin, Dahl, dan Wagner, 2010; Yowell, Katz, Reardon, dan Peterson, 2012).

Oleh karena itu, pikiran negatif penting untuk diidentifikasi, dilawan dan diubah untuk membantu individu mengambil keputusan karir (Sampson dkk. dikutip dalam Chason dkk., 2013). Pikiran negatif tersebut dapat diidentifikasi dengan career thoughts inventory (Peterson, Sampson, Lenz, dan Reardon dikutip dalam Isaacson dan Brown, 2012; Brown, 2012; Zunker, 2014). Career 
Thoughts Inventory (CTI) mengukur tidak berfungsinya pikiran (dysfunctional thinking) berhubungan dengan asumsi, sikap, tingkah laku, keyakinan, perasaan, rencana-rencana atau strategi-strategi yang berhubungan dengan pilihan karir. Atribut-atribut tersebut dipercaya dapat menghalangi individu membuat keputusan karir (Austin, Dahl, dan Wagner, 2010).

Intervensi yang sesuai untuk mengatasi hambatan-hambatan dalam pengambilan keputusan jurusan kuliah adalah dengan pendekatan career informationprocessing model. Pendekatan career information-processing model adalah pendekatan yang menekankan pikiran dan memori dalam proses menyelesaikan masalah dan mengambil keputusan karir (Henderson, 2009).

Pendekatan career informationprocessing model akan dijadikan pendekatan dalam konseling karir yang akan dilakukan pada siswa yang mengalami kebingungan dalam mengambil jurusan kuliah.

Penelitian-penelitian sebelumnya hanya menguji korelasi mengenai hubungan antara career thoughts dengan pengambilan keputusan karir dari sudut pandang career information-processing (Chason dkk., 2013; Austin dkk., 2010; Yowell dkk., 2011). Hasil penelitian tersebut mengatakan bahwa pikiran negatif dapat menyebabkan difungsional kognisi sehingga menghalangi individu mengambil keputusan karir. Berkurangnya pikiran negatif dapat membuat individu mampu mengambil keputusan terhadap karirnya (Austin dkk., 2010).

Penelitian tersebut memberi saran untuk peneliti selanjutnya bahwa career thoughts inventory dapat dijadikan bahan asesmen untuk mengetahui letak permasalahan individu dalam mengambil keputusan karir sehingga dapat diberikan intervensi yang tepat (Chason dkk., 2013; Austin dkk., 2010; Yowell dkk., 2011). Selain itu, Penelitian tersebut juga memberi saran untuk dapat mengem- bangkan career information-processing model sebagai intervensi untuk membantu individu mengambil keputusan karir (Chason dkk., 2013; Austin dkk., 2010; Yowell dkk., 2011). Terdapat lima fase/ tahap dalam pendekatan career information-processing model disebut dengan CASVE (communication, analysis, synthesis, valuing, dan excecution).

Berbagai studi menunjukkan bahwa setiap individu dengan permasalahan yang berbeda dalam pengambilan keputusan karir memerlukan pendekatan yang berbeda pula untuk membantunya membuat keputusan karir (Amit dan Gati; Amit dan Sagiv; Mau; Tinsley; Rushing; Zakay dan Tsal dikutip dalam Gati dkk., 2014). Selain aspek emosional dan personality yang memengaruhi pengambilan keputusan dalam karir, aspek kognitif berupa pemroresan informasi juga memengaruhi dalam pengambilan keputusan (Gati dkk., 2014).

Keberhasilan siswa dalam pemilihan karir yang tepat bukan suatu hal yang mudah dilakukan. Agar siswa mengambil keputusan yang tepat dalam jurusan kuliahnya diperlukan sebuah intervensi yang dapat membantu siswa dalam menetapkan pilihan karirnya. Permasalahan yang dialami oleh siswa MAN Y Jakarta mengenai kebingungan pilihan karirnya perlu dicarikan pemecahannya. Oleh karena itu, dalam penelitian ini digunakan pendekatan career informationprocessing yang diterapkan dalam proses konseling untuk membantu siswa membuat keputusan terhadap karirnya (jurusan kuliah) (Peterson, Sampson, Reardon, dan Lenz dikutip dalam Brown, 2012).

\section{Definisi Pengambilan Keputusan Karir}

Parsons (dikutip dalam Peter, Creed, Wong, dan Hood, 2009) mendefinisikan pengambilan keputusan karir adalah proses individu memahami dirinya dan dunia pekerjaan serta kemampuan 
mengintegrasikan antara dirinya dengan pekerjaannya. Dari definisi karir dan pengambilan keputusan di sub bab sebelumnya maka dapat diambil simpulan bahwa career decision-making adalah proses pengumpulan informasi alternatifalternatif pilihan yang relevan kemudian memutuskan pilihan dari sekian banyak alternatif pilihan tersebut untuk suatu peran yang khas dari individu yang dibentuk berdasarkan sesuatu yang dipilih dan tidak dipilih oleh individu tersebut.

\section{Definisi Career Information-Processing Model}

Pendekatan career informationprocessing merupakan integrasi dari teori pemecahan masalah karir yang berasal dari Psikologi Kognitif dengan perspektif dari pemrosesan informasi individu untuk menemukan jalan dalam memilih karir dan mengambil keputusan (Peterson, Sampson, Reardon, dan Lentz dikutip dalam Strohm, 2008). Pendekatan career information-processing adalah pendekatan yang bertujuan membantu individu untuk menjadi penyelesai masalah dan pengambil keputusan yang lebih baik (Patton dan McMahon, 2014).

Fase/ tahap career informationprocessing model terdiri dari lima tahap yang disebut dengan siklus CASVE (Peterson, Sampson, Reardon, dan Lenz dikutip dalam Paivandy, 2009; Isaacson dan Brown, 1997; Brown, 2012; Zunker, 2012; Patton dan McMahon, 2014).yaitu:

(1) Communication (komunikasi), Analysis (analisis), (3) Synthesis (sintesis),

(4) Valuing (nilai), dan (5) Excecution (eksekusi)

Pada tahap komunikasi, individu menyadari bahwa mereka butuh untuk mengambil keputusan berdasarkan komunikasi internal dan eksternal yang mereka terima berupa informasi dari dirinya dan dari lingkungannya (Paivandy, 2008). Pada tahap komunikasi terjadi proses memasukkan informasi ke dalam memori disebut encoding (Zunker, 2012;
Santrock, 2011). Pada tahap komunikasi ini individu mengidentifikasi masalah internal atau eksternal yang dihadapi (Henderson, 2009).

Pada tahap kedua yaitu tahap analisis, individu menganalisis dirinya, pilihanpilihannya, dan faktor-faktor yang memengaruhi dirinya dan pilihannya (Paivandy, 2008). Individu menganalisis pentingnya pengetahuan diri meliputi perasaan, tingkah laku, tekanan dan orang lain dalam memengaruhi keputusan (Paivandy, 2008). Pada tahap ketiga yaitu tahap sintesis, individu menuliskan alternatif-alternatif untuk mengambil keputusan (Paivandy, 2008). Pada tahap sintesis terdapat dua tahap yaitu tahap elaborasi dan kristalisasi. Tahap elaborasi yaitu tahap berpikir divergen bahwa individu mempertimbangkan berbagai macam pilihan alternatif. Sementara itu tahap kristalisasi adalah tahap berpikir konvergen yaitu membatasi pilihanpilihan yang bertentangan dengan diri individu (Henderson, 2009).

Pada tahap keempat yaitu tahap valuing (nilai), tahap individu mengevaluasi biaya serta keuntungan setiap alternatif dan memperkirakan penerimaan orang lain atas pilihannya (Sampson dikutip dalam Henderson, 2009). Pada tahap valuing individu sudah membuat pilihan yang diprioritaskan tiga sampai lima pilihan (Henderson, 2009). Tahap terakhir adalah tahap eksekusi, pada tahapan ini individu membuat/ menyusun rencana atau strategi untuk mencapai pilihan pertamanya (Henderson, 2009).

Dari tahap career informationprocessing model di atas dapat disimpulkan bahwa untuk mencapai pengambilan keputusan terdapat lima tahap yang disebut CASVE yaitu tahap communication, analysis, synthesis, valuing dan execution.

Santrock (2001) mengatakan bahwa perspektif yang dapat memahami perkembangan kognitif remaja adalah perspektif information-processing. Sieglar 
(dikutip dalam Santrock, 2001) mendeskripsikan tiga karakteristik utama dari perspektif information-processing, yaitu: a) thinking, berpikir adalah memproses informasi. Ketika remaja menerima, memberi kode, menampilkan, dan menyimpan informasi yang diperoleh dari lingkungan sekitar, mereka terlibat dalam berpikir; b) change mechanism, pendekatan information-processing harus berfokus pada peran mekanisme perubahan dalam perkembangan; c) selfmodification, remaja menggunakan pengetahuan dan strategi yang telah mereka pelajari sebelumnya untuk mengadaptasi respon mereka terhadap situasi yang baru dipelajari.

Pendekatan information-processing ini dapat dilihat aplikasinya pada pengambilan keputusan. Menurut Santrock (2001), masa remaja adalah saat dimana terjadi peningkatan pengambilan keputusan mengenai masa depan, menentukan teman mana yang dipilih, apakah mereka akan kuliah. Remaja akhir lebih kompeten dalam mengambil keputusan dibandingkan remaja awal (Papalia, Olds, dan Feldman, 2007). Pada remaja akhir, pengambilan keputusan mereka sudah hampir menyerupai orang dewasa. Mereka sudah dapat melaksanakan strategi dengan cara yang lebih fleksibel dan dapat memperhitungkan resiko dan konsekuensi yang mungkin terjadi (Papalia dkk., 2007). Kemampuan remaja akhir dalam menggali pilihan, mengantisipasi konsekuensi dan mengevaluasi kredibilitas sumber informasi juga lebih baik apabila dibandingkan remaja awal (Papalia dkk., 2007).

\section{Metode Penelitian}

Partisipan pada penelitian ini adalah 7 siswa kelas 11 IPA 2, MAN Y Jakarta yang memperoleh skor career thoughts inventory (CTI) tinggi dari 26 siswa di kelas 11 IPA 2. Karakteristik partisipan pada penelitian ini meliputi: (a) Siswa yang memperoleh skor career thought inventory (CTI) tinggi, (b) Siswa yang berusia 15-18 tahun, dan (c) Siswa pada level kelas XI pada tahun ajaran 20152016.

Desain penelitian yang digunakan dalam penelitian ini adalah kuantitatif dengan metode eksperimen one-group pre-test post-test design (Liche, Yulianto dan Setiadi, 2005). Penelitian ini bertujuan untuk melihat efektivitas intervensi career counseling dengan pendekatan career information-processing model terhadap career decision-making siswa. Efektivitas dari career counseling dengan pendekatan career information-processing model dilihat dari perbedaan antara pre-test dengan post-test. Agar lebih meyakinkan dalam simpulannya, digunakan analisis statistik dengan correlated data t-test/ paired-samples t-test. Apabila ada perbedaan skor pre-test dan skor post-test dimana skor post-test lebih rendah secara signifikan, maka dapat disimpulkan bahwa career counseling dengan pendekatan career information-processing model efektif membantu career decision-making siswa.

Penelitian ini dilaksanakan pada hari Kamis di Ruang Multimedia MAN Y Jakarta sedangkan pada hari Sabtu penelitian dilaksanakan di ruang kelas 11 IPA 2, MAN Y Jakarta.

Dalam penelitian ini ada dua alat ukur yang digunakan yaitu Career Thoughts Inventory (CTI) dan Career Decision Scale (CDS). CTI digunakan sebelum penelitian yaitu untuk memperoleh partisipan yang akan diteliti.

Partisipan dengan skor CTI tinggi akan diberikan intervensi career counseling dengan pendekatan career information-processing model. Alat ukur CTI (career thoughts inventory) diadaptasi dari Sampson, Peterson, Lenz, Reardon, dan Saunders (1996) yang digunakan untuk mengukur pikiran-pikiran negatif yang menghalangi career decisionmaking. 
CTI terdiri dari 3 dimensi dengan total 48 butir. Dimensi dalam CTI meliputi, (1) decision-making confusion (DMC), (2) commitment anxiety (CA), dan (3) external conflict (EC).

Dimensi decision-making confusion terdiri dari 14 butir, dimensi commitment anxiety terdiri dari 10 butir, dan dimensi external conflict terdiri dari 5 butir.

Alat ukur kedua yang digunakan pada penelitian ini adalah alat ukur career decision scale (CDS). CDS terdiri dari 2 dimensi dengan total 19 butir. Dimensi dalam CDS meliputi, (1) certainty, dan (2) indecision.

Dimensi certainty terdiri dari 3 butir, dan dimensi indecision terdiri dari 16 butir. Alat ukur CDS diadaptasi dari Osipow (dikutip dalam Brown, 2012) digunakan untuk mengukur kemampuan dalam membuat pengambilan keputusan karir.

Partisipan dikatakan mampu mengambil keputusan jurusan kuliah (career decision-making) apabila skor CDS setelah intervensi lebih kecil daripada sebelum diberikan intervensi. Semakin tinggi skor CDS mencerminkan partisipan tidak mampu/ kesulitan dalam career decision-making.

Sebelum penelitian ini dilakukan, peneliti menganalisis permasalahan menggunakan teori-teori career decisionmaking dan career informationprocessing model. Kemudian, peneliti melakukan studi literatur terhadap penelitian-penelitian serupa yang dilakukan sebelumnya dan teori terkait. Berdasarkan teori dan jurnal penelitian, peneliti menyusun modul career counseling dengan pendekatan career information-processing model dan mengadaptasi alat ukur career thoughts inventory dan career decision scale.

Pengujian validitas yang dilakukan terhadap alat ukur career decision scale pada penelitian ini adalah (1) content validity dan (2) face validity.
Content validity alat ukur dilakukan melalui pembimbing, sedangkan face validity dilakukan melalui partisipan setara. Partisipan setara adalah individu yang memiliki usia 15- 18 tahun, duduk di kelas 11, sekolah yang memiliki kurikulum yang sama dengan sekolah yang menjadi setting penelitian.

Tahap persiapan berikutnya adalah tryout terhadap alat ukur career thoughts inventory dan career decision scale untuk mendapatkan reliabilitas alat ukur. Tryout dilakukan terhadap partisipan yang setara dengan partisipan dalam penelitian ini. Partisipan setara yang dimaksud adalah siswa yang berada di kelas 11, dan bersekolah di sekolah yang memiliki kurikulum pendidikan sama. Jumlah partisipan tryout adalah 31 partisipan, atau satu kelas, kelas 11 MAN X Jakarta.

Setelah alat ukur valid dan reliabel, berarti alat ukur siap digunakan. Selain persiapan materi penelitian, peneliti juga menghubungi sekolah MAN Y Jakarta untuk koordinasi dan konfirmasi mengenai izin melakukan penelitian dan teknis pelaksanaannya. Selanjutnya setelah mendapatkan izin melakukan penelitian, peneliti bekerja sama dengan guru bimbingan konseling mendata kelas dengan jumlah siswa terbanyak yang mengalami hambatan dalam penentuan karir.

Selanjutnya, setelah mendapatkan data kelas dengan jumlah siswa yang mengalami hambatan penentuan karir telah diidentifikasi jumlah terbanyak, peneliti kemudian melakukan screening dengan memberikan alat ukur CTI yaitu di kelas 11 IPA 2. Berdasarkan screening dengan menggunakan alat ukur CTI, diperoleh tujuh siswa dengan skor CTI tinggi. Hal tersebut mengindikasikan bahwa siswa mengalami hambatan dalam penentuan karir. Ketujuh siswa dengan skor CTI tinggi kemudian diberikan pretest alat ukur CDS (career decision scale).

Setelah tahap persiapan selesai dilakukan maka selanjutnya peneliti 
melakukan intervensi kepada kelompok eksperimen. Peneliti memberikan 9 sesi intervensi career counseling dengan pendekatan career information-processing model dengan tahapan fase CASVE (communication, analysis, synthesis, valuing dan execution) kepada 7 siswa kelas 11 IPA 2, MAN Y Jakarta.

Setelah intervensi career counseling selesai dilakukan, maka selanjutnya partisipan diberikan post-test alat ukur CDS. Selanjutnya, penelitian ini memasuki tahap evaluasi. Pada tahap evaluasi, seluruh data yang diperoleh selama tahap persiapan dan pelaksanaan diinput, diolah dan dianalisis. Pengolahan data penelitian diperoleh dari nilai pre-test dan post-test dengan menggunakan analisis statistik parametrik paired sample t-test karena data berdistribusi normal. Artinya parametric paired sample t-test yaitu membandingkan dua data yang berpasangan dari setiap sampel dalam penelitian. Dalam proses evaluasi data, peneliti menggunakan program SPSS (Statistical Product and Services Solution) versi 21 for Windows.

\section{Hasil Penelitian dan Pembahasan}

Pelaksanaan intervensi diberikan kepada tujuh partisipan yaitu partisipan AS, GNQ, JIR, LA, NM, RE dan RZ. Partisipan AS berusia 16 tahun berjenis kelamin wanita, partisipan GNQ berusia 16 tahun berjenis kelamin laki-laki, partisipan JIR berusia 16 tahun berjenis kelamin wanita, partisipan LA berusia 16 tahun berjenis kelamin wanita, partisipan NM berusia 16 tahun berjenis kelamin wanita, partisipan RE berusia 16 tahun berjenis kelamin wanita dan partisipan RZ berusia 16 tahun berjenis kelamin wanita.

Intervensi yang dilakukan pada penelitian ini yaitu career counseling dengan pendekatan career informationprocessing model dengan tahapan CASVE (Communication, Analysis, Synthesis, Valuing, dan Execution). Dari tahapan CASVE tersebut dibuat menjadi 9 sesi. Intervensi dilakukan seminggu dua kali pada hari Kamis dan Sabtu di MAN Y Jakarta.

\section{Fase Communication (C)}

Pada fase communication dibagi dalam dua sesi yaitu sesi 1 dan 2 . Fase ini dilaksanakan pada hari Kamis, 29 Oktober 2015 dari pukul 13.00-15.00 WIB, bertempat di Ruang Multimedia, MAN Y Jakarta.

Sesi 1. Pada sesi 1 dapat ditarik kesimpulan bahwa pelajaran yang disukai partisipan pada umumnya pelajaran yang santai (tidak banyak berpikir), gurunya mengasyikkan dan pelajaran tersebut ada hubungannya dengan cita-cita.

Sesi 2. Pada sesi 2 partisipan mengidentifikasi masalah-masalah yang dihadapi dalam mengambil keputusan jurusan kuliah serta memilah masalah tersebut ke dalam masalah internal dan eksternal (worksheet 2). Pada sesi 2 dapat diketahui bahwa masalah dominan yang dihadapi partisipan cenderung berasal dari dalam diri (internal) seperti prestasi nilai akademik yang rendah, kecemasan tidak dapat menekuni kuliah sampai selesai, ketidakyakinan pada jurusan yang dipilih karena tidak mengetahui bakat dan minat diri, serta kurangnya usaha dalam mencari informasi mengenai jurusan-jurusan kuliah dan dunia kerja. Sedangkan, masalah dari luar diri (eksternal) yang dihadapi partisipan umumnya masalah biaya kuliah dan perbedaan pendapat/ keinginan dengan orang tua.

\section{Fase Analysis (A)}

Fase analysis dibagi dalam dua sesi yaitu sesi 3 dan sesi 4 yang dilaksanakan pada hari Sabtu, 31 Oktober 2015 dari pukul 08.00-12.30 WIB. Seluruh partisipan hadir pada pertemuan sesi 3 dan 4 . Pada sesi 3, partisipan mengerjakan psikotes minat dan bakat serta merekap nilai pelajaran dengan prestasi tertinggi dan terrendah.

Sesi 3. Pada rancangan intervensi dijadwalkan bahwa sesi 3 dimulai pukul 
08.00 WIB. Pada sesi 3, dapat ditarik kesimpulan bahwa pada umumnya partisipan memperoleh nilai tinggi pada pelajaran yang berhubungan dengan pemahaman agama dan pelajaran yang terkait hafalan. Sedangkan, partisipan memperoleh nilai rendah pada pelajaran hitungan.

Sesi 4. Sesi 4 dilaksanakan pada hari yang sama dengan sesi 3 yaitu Sabtu, 31 Oktober 2015. Sesi 4 dilaksanakan setelah ketujuh partisipan istirahat dan makan. Pada sesi 4 dapat disimpulkan bahwa kegiatan yang umum mampu dilakukan partisipan adalah menghafal. Sedangkan partisipan kesulitan dalam hal memecahkan persoalan hitungan. Sifat positif partisipan pada umumnya berkaitan dengan kepedulian pada orang-orang di sekitarnya, sedangkan sifat negatif partisipan pada umumnya mengenai kurangnya motivasi dan daya juang dalam belajar serta managemen waktu. Kegiatan yang disukai partisipan cenderung berkaitan dengan kegiatan yang menyenangkan, dan kegiatan yang tidak disukai partisipan cenderung merupakan kegiatan yang berhubungan dengan belajar.

\section{Fase Synthesis (S)}

Fase synthesis terdiri dari satu sesi yaitu sesi 5. Fase synthesis ini dilaksanakan pada hari Kamis, 5 November 2015 dari pukul 12.45-14.45 WIB.

Sesi 5. Pada sesi 5 diketahui bahwa jurusan-jurusan yang diminati partisipan pada umumnya merupakan jurusan yang berhubungan dengan bidang kegiatan ilmiah dan sosial. Sedangkan, pada jurusan yang diprioritaskan dapat disimpulkan bahwa jurusan yang diprioritaskan partisipan pada umumnya berhubungan dengan bidang minat sosial.

\section{Fase Valuing (V)}

Pada fase valuing partisipan sudah mulai memilih tiga jurusan prioritas dengan mempertimbangkan hambatan dan konsekuensi dipadankan dengan potensi, personality, dan passion diri. Fase valuing ini dibagi menjadi dua sesi yaitu sesi 6 dan 7 yang dilaksanakan pada hari Sabtu, 7 November 2015 pukul 09.00-12.00 WIB.

Sesi 6. Pada sesi 6 diketahui bahwa partisipan memiliki hambatan dalam masalah biaya kuliah. Kemudian, pada kemungkinan kesulitan yang dihadapi saat kuliah nanti adalah ketakutan tidak dapat mengikuti pelajaran saat kuliah nanti pada jurusan yang dipilihnya.

Sesi 7. Pada sesi 7 dapat diketahui bahwa kelebihan jurusan yang dipilih pada umumnya karena akan memperoleh penghasilan (gaji/ pendapatan) yang besar. Sedangkan, kekurangan jurusan yang dipilih pada umumnya bukan dari jurusan itu sendiri namun lebih pada diri pribadi partisipan seperti kurang motivasi dan daya juang dalam belajar, kesabaran dalam menghadapi situasi yang tidak menyenangkan, serta peningkatan kemampuan diri meliputi jiwa kreatif, kemampuan menyesuaikan diri, dan kemampuan berbahasa.

\section{Fase Execution (E)}

Fase ini dibagi menjadi dua sesi yaitu sesi 8 dan 9 dilaksanakan pada hari Kamis, 12 November 2015 pukul 12.4515.00 WIB.

Sesi 8 dan 9. Pada sesi 8 dan 9 dapat disimpulkan bahwa terdapat tiga aspek yang dilakukan dalam mencapai jurusan yang dipilih yaitu aspek kognitif, afektif dan psikomotorik. Pada aspek kognitif, partisipan berusaha untuk meraih cita-cita jurusan yang diinginkan yaitu dengan meningkatkan prestasi akademik. Pada aspek afektif, partisipan mengusahakan berdoa pada Allah swt., meningkatkan keyakinan, motivasi dan daya juang. Pada aspek psikomotorik, untuk meraih citacita jurusan yang diinginkan yaitu dengan mengunjungi fakultas pilihan kemudian bertanya pada mahasiswa yang kuliah di jurusan tersebut untuk memperoleh infor- 
masi mengenai jurusan tersebut. Dengan demikian dapat ditarik kesimpulan bahwa partisipan lebih mengutamakan aspek kognitif untuk dapat mencapai jurusan yang diinginkan dan kurang memberdayakan aspek afektif.

Setelah selesai intervensi maka partisipan mengerjakan post-test yang dilakukan pada hari Kamis, 19 November 2015 di Ruang Multimedia MAN Y Jakarta. Pelaksanaan post-test diberikan kepada tujuh partisipan kelas 11 IPA 2 yaitu seminggu setelah intervensi selesai diberikan dengan menggunakan alat ukur career decision scale (CDS).

Sebelum dilakukan uji beda antara skor pre-test dan post-test, maka dilakukan uji normalitas terlebih dahulu untuk mengetahui data yang diperoleh sebarannya normal atau tidak dengan menggunakan 1-sample $K S$ pada SPSS versi 21. Dari hasil uji normalitas diketahui bahwa sebaran data normal yaitu $\mathrm{p}=0.940 \quad(\mathrm{p}>0.05) \quad$ dengan hasil Kolmogorov-Smirnov $=0.532$. Oleh karena sebaran data yang dimiliki berdistribusi normal, maka selanjutnya digunakan uji beda dengan parametrik paired sample ttest.

Dari tabel uji beda dengan paired sample t-test diperoleh $\mathrm{t}=8.576$ dengan $\mathrm{p}=0.000(\mathrm{p}<0.01)$ artinya adalah terdapat perbedaan sebelum dan sesudah intervensi. Dengan kata lain, maka dapat disimpulkan bahwa adanya intervensi career counseling dengan pendekatan career information-processing model efektif membantu career decisionmaking pada siswa.

Perbandingan skor pre-test dan posttest dapat dilihat pada tabel di bawah ini.

Tabel 1.

Perbandingan Skor Pre-test dan Post-Test

\begin{tabular}{cccc}
\hline Nama & Pretest & Posttest & Gain Score \\
\hline AS & 31 & 12 & 19 \\
GNQ & 41 & 21 & 20 \\
JIR & 38 & 14 & 24 \\
LA & 49 & 13 & 36
\end{tabular}

\begin{tabular}{lrrr} 
NM & 44 & 10 & 34 \\
$\mathrm{RE}$ & 51 & 18 & 33 \\
$\mathrm{RZ}$ & 53 & 9 & 44 \\
\hline
\end{tabular}

Berdasarkan perbandingan skor pretest dan post-test pada tabel 1 di atas diketahui bahwa perbedaan skor pre-test dan post-test pada AS sebesar 19, pada GNQ sebesar 20, pada JIR sebesar 24, pada LA sebesar 36, pada NM sebesar 34, pada RE sebesar 33, dan pada RZ sebesar 44. Maka dapat disimpulkan bahwa perbedaan tertinggi terdapat pada RZ sebesar 44, dan terrendah pada AS sebesar 19.

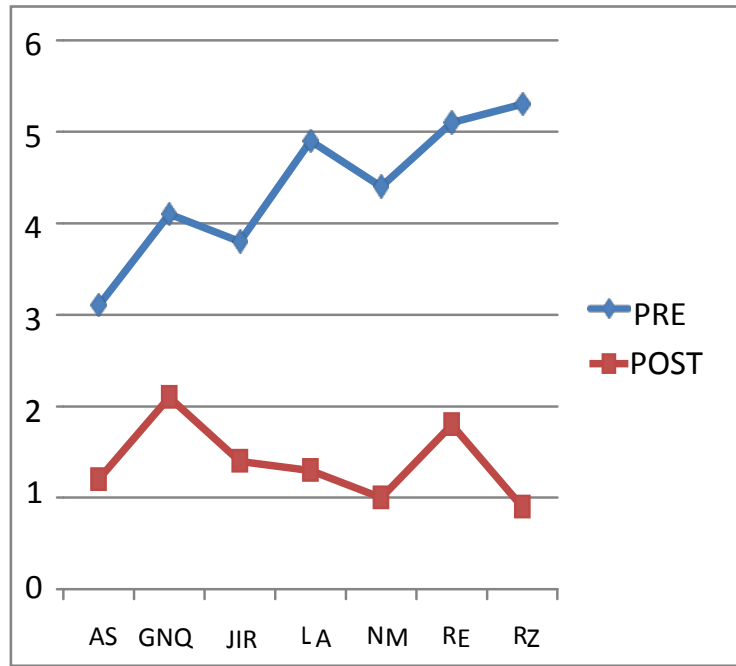

Grafik 1. Perbandingan Skor Pre-test dan Post-test

Dari selisih skor yang diperoleh sesudah (post-test) dan sebelum (pre-test) pada tabel 1 juga dapat disimpulkan bahwa intervensi career counseling dengan pendekatan career informationprocessing model efektif membantu career decision-making pada siswa. Perbandingan tersebut juga dapat dilihat dalam bentuk grafik 1 .

Berdasarkan grafik 1 di atas dapat dilihat bahwa terdapat perubahan berupa penurunan dari skor pre-test ke post-test. Hal ini mengindikasikan bahwa semua partisipan terbantu dengan intervensi yang didapatkan sehingga partisipan mampu mengambil keputusan jurusan kuliah. Partisipan dikatakan mampu mengambil 
keputusan jurusan kuliah jika skor CDS yang diperoleh rendah.

Perbedaan skor pre-test dan posttest yang paling mencolok adalah pada partisipan RZ. Hal tersebut disebabkan bahwa dari awal partisipan RZ memperoleh skor paling tinggi saat pre-test yang artinya partisipan RZ lebih banyak mengalami kesulitan dalam mengambil keputusan jurusan kuliah dibandingkan partisipan lainnya. Namun, setelah diberikan intervensi penurunan skor partisipan RZ paling banyak dibandingkan yang lain itu artinya partisipan RZ sangat terbantu dengan intervensi yang didapatkan.

Hasil penelitian tersebut sejalan dengan penelitian sebelumnya yang dilakukan oleh Chason dkk. (2013), Austin dkk. (2010) dan Yowell dkk. (2011) bahwa dengan berkurangnya hambatan/ kesulitan yang dihadapi dalam mengambil keputusan karir dapat membuat individu mampu mengambil keputusan terhadap karirnya.

Pada fase communication, partisipan mengidentifikasi serta mengungkapkan masalah yang dihadapi dalam mengambil keputusan jurusan kuliah. Kemampuan dalam merumuskan masalah yang dihadapi merupakan langkah awal dalam problem solving (Solso, 1991). Pada fase ini partisipan jadi menyadari masalahmasalah yang dihadapi yang disebut juga insight yang dapat menuntun individu dalam memecahkan masalah yang dihadapi (Walgito, 2007).

Kesadaran serta pemahaman individu mengenai masalah yang dihadapi dapat memengaruhi keberhasilan sebuah konseling (Saam, 2013). Sikap terbuka partisipan dalam mengungkapkan masalah yang dihadapi (self-disclosure) di awal sesi intervensi merupakan salah satu sebab keberhasilan intervensi yang dilakukan (Saam, 2013).

Menurut Collin dan Miller (dikutip dalam Papalia dkk., 2007) mengatakan bahwa self-disclosure adalah pengungkapan informasi diri kepada individu lain. Self-disclosure ini akan menghasilkan suatu ketertarikan, kehangatan, dan kepercayaan kepada orang lain (Papalia dkk., 2007).

Ketertarikan dan kepercayaan dalam sesi konseling antara klien terhadap konselor merupakan salah satu keberhasilan dari sebuah sesi konseling (Saam, 2013).

Self-disclosure yang terjadi pada fase communication meliputi pengungkapan masalah yang dihadapi dalam mengambil keputusan jurusan kuliah. Semua partisipan terbuka kepada konselor mengenai masalah yang dihadapi.

Pada fase communication masalah yang pada umumnya dihadapi partisipan cenderung berasal dari dalam diri (internal) seperti prestasi nilai akademik yang rendah, kecemasan tidak dapat menekuni kuliah sampai selesai, ketidakyakinan pada jurusan yang dipilih karena tidak mengetahui bakat dan minat diri, serta kurangnya usaha dalam mencari informasi mengenai jurusan-jurusan kuliah dan dunia kerja. Selain itu, juga terdapat masalah dari luar diri (eksternal) yang dihadapi partisipan meliputi masalah biaya kuliah (Sampson, Peterson, Reardon, dan Lenz, 2000) dan perbedaan pendapat/ keinginan dengan orang tua.

Pada fase analysis, partisipan menuliskan rata-rata pelajaran dengan nilai tertinggi diharapkan dengan mengetahui prestasi yang telah diraihnya dapat meningkatkan self-efficacy partisipan. Bandura (dikutip dalam Santrock, 2011) mengatakan bahwa pengalaman kesuksesan individu dapat meningkatkan selfefficacy. Sedangkan, mengetahui penyebab nilai yang rendah pada pelajaran tertentu menjadi awal untuk memecahkan masalah dalam meningkatkan prestasi nilai pada pelajaran tersebut (Solso, 1991).

Pada fase analysis, partisipan juga menganalisa diri mengenai kemampuan, sifat positif dan negatif serta kegiatan yang disukai dan tidak disukai. Dari hasil worksheet kegiatan yang disukai partisi- 
pan diketahui bahwa semua partisipan menyukai kegiatan bermain dan bercengkrama dengan teman. Hal ini sejalan dengan penelitian yang dilakukan oleh Csikszentmihalyi dan Larson (dikutip dalam Stewart dan Friedman, 1987) bahwa $24 \%$ remaja menyukai aktivitas sosial dengan teman, sedangkan yang menyukai aktivitas membaca hanya $3 \%$.

Hal tersebut sesuai dengan kegiatan yang tidak disukai partisipan adalah belajar. Kegiatan yang disukai dan tidak disukai partisipan mendukung hasil pemeriksaan psikologis bahwa pada partisipan AS, GNQ, JIR, LA, dan NM tidak ada motivasi untuk belajar. Selain itu, pada semua partisipan tidak ada daya juang untuk berprestasi.

Pada fase synthesis, partisipan mempertimbangkan berbagai macam alternatif pilihan jurusan kemudian membatasi pilihan-pilihan yang bertentangan dengan dirinya. Partisipan telah memiliki informasi mengenai masalah yang dihadapi kemudian telah menganalisa mengenai diri mereka. Informasi tersebut kemudian diinterpretasi dan diproses dalam kognitif mereka kemudian disimpan untuk dipergunakan jika dibutuhkan.

Pada fase sintesa ini informasi yang telah diperoleh pada fase sebelumnya digunakan oleh partisipan untuk melakukan sintesa terhadap alternatif pilihan jurusan dengan pilihan-pilihan yang tidak sesuai (Papalia dkk., 2007). Kemudahan partisipan dalam mengingat informasi yang telah didapatkan pada fase sebelumnya didukung oleh kemampuan mengingat mereka yang di atas rata-rata berdasarkan hasil pemeriksaan psikologis.

Pada fase valuing, partisipan dapat mengenali hambatan, kemungkinan kesulitan yang dihadapi, serta kelebihan dan kekurangan dari jurusan yang dipilihnya. Hal tersebut sesuai dengan tahap perkembangan kognitif dari Piaget (dikutip dalam Santrock, 2011) bahwa tahap perkembangan kognitif remaja berada pada tahap formal operasional sehingga remaja mampu menganalisa masalah dan mempertimbangkan konsekuensi atas tindakannya.

Pada fase execution, partisipan sudah mampu mengambil keputusan satu jurusan tertentu serta membuat strategi dalam mencapai jurusan tersebut. Keputusan tersebut didapatkan setelah partisipan mengumpulkan berbagai informasi mengenai masalah yang dihadapi, yang mampu dilakukan dan tidak mampu dilakukan oleh diri, sifat positif dan negatif diri, kegiatan yang disukai dan tidak disukai, berbagai alternatif jurusan, hasil pemeriksaan psikologis mengenai potensi, kepribadian dan minat kemudian mengevaluasi hambatan dan kemungkinan kesulitan serta kelebihan dan kekurangan jurusan. Hal ini sejalan dengan definisi dari career decision-making yaitu proses pengumpulan informasi alternatif pilihan yang relevan kemudian memutuskan pilihan dari sekian banyak alternatif pilihan (Peter dkk., 2009).

Kelebihan dari penelitian ini adalah evidence-based intervention sehingga intervensi career counseling dengan pendekatan career information-processing model dapat dijadikan model intervensi career decision-making. Kekurangan dari penelitian ini adalah pada sesi analysis dalam lembar worksheet 3 mengenai analisa nilai rapor dengan nilai tertinggi dan terrendah tidak disertai penyebab mampu meraih nilai tinggi dan penyebab mendapat nilai rendah. Padahal penyebab dapat meraih nilai tinggi dan rendah dapat dijadikan bahan evaluasi agar dapat mempertahankan prestasi yang sudah diperoleh serta mengetahui penyelesaian masalah agar tidak terulang mendapat nilai rendah.

Selain itu, pada sesi valuing dibahas mengenai hambatan dan kemungkinan kesulitan yang dihadapi ketika memilih jurusan tertentu namun tidak disertai solusi untuk mengatasi hambatan dan kemungkinan kesulitan yang dihadapi. 
Keberhasilan intervensi career counseling dengan pendekatan career information-processing model dalam membantu career decision-making pada siswa adalah karena rancangan modul career counseling yang sistematis dan bertahap serta adanya asesmen sebelum diberikan intervensi sehingga diketahui masalah yang dihadapi dan kebutuhan dari partisipan yang diberikan intervensi.

Selain itu, keberhasilan intervensi ini juga dipengaruhi oleh dua faktor yaitu faktor partisipan dan faktor konselor (peneliti/ pemberi intervensi). Keberhasilan intervensi penelitian ini dari faktor partisipan meliputi: (1) keterbukaan partisipan, (2) pemahaman partisipan tentang dirinya, (3) pemahaman partisipan tentang ma-salahnya, (3) keinginan dan motivasi partisipan untuk berubah, serta (3) komitmen partisipan untuk melaksanakan kegiatan intervensi yang dilaksanakan.

Sedangkan dari faktor konselor (peneliti/ pemberi intervensi), yaitu meliputi: (1) kompetensi konselor, (2) pandangan positif partisipan tentang keahlian konselor, (3) kepercayaan partisipan pada konselor, dan (4) daya tarik positif partisipan kepada konselor.

Tahapan intervensi yang dilakukan kepada partisipan dalam penelitian ini dimulai dengan usaha menciptakan suasana keterbukaan dalam mendiskusikan masalah yang dihadapi dalam mengambil jurusan kuliah. Partisipan diberikan kebebasan untuk mengemukakan pendapatnya terkait hambatan yang dialami dalam mengambil keputusan jurusan kuliah. Ketika partisipan mulai membuka diri kemudian merasa tergugah atau tertantang untuk mengatasi hambatan yang dialami dalam mengambil keputusan jurusan kuliah, partisipan penelitian pada akhirnya lebih mudah memahami diri dan masalah yang dihadapinya. Sehingga, tumbuh sebuah komitmen dalam diri partisipan untuk mengikuti setiap sesi kegiatan intervensi.

\section{Simpulan dan Saran}

Penelitian ini bertujuan untuk menguji apakah career counseling dengan pendekatan career information-processing model efektif dalam membantu career decision-making pada siswa MAN Y Jakarta. Pengolahan data pada penelitian ini menggunakan uji statistik paired sample t-test. Berdasarkan uji statistik tersebut diperoleh signifikansi intervensi $\mathrm{t}=8.576$ dan $\mathrm{p}=0.000<0,01$. Dengan demikian dapat disimpulkan bahwa intervensi career counseling dengan pendekatan career information-processing model terbukti efektif dalam membantu career decision-making pada siswa MAN Y Jakarta.

Terdapat beberapa saran praktis bagi pihak-pihak yang terkait dalam penelitian ini antara lain.

Kepada siswa, berlatih mengambil keputusan dengan hal-hal yang kecil seperti memutuskan untuk ikut pergi dengan orang tua atau belajar di rumah saat banyak tugas sekolah;

Kepada orang tua, terkait dengan keputusan pilihan jurusan yang diambil oleh anak, maka sangat baik apabila orang tua membantu anak untuk mampu mengambil keputusan dimulai dari hal yang sederhana seperti memberi kesempatan pada anak untuk memutuskan memilih kegiatan ekstrakurikuler yang akan diikutinya.

Kepada guru bimbingan konseling, disarankan untuk melakukan asesmen kebutuhan siswa setiap awal tahun ajaran agar mengetahui kebutuhan siswa. Kemudian, mem-buat rancangan layanan bimbingan karir dengan sistematis. Selain itu, meningkatkan pengetahuan dan wawasan mengenai berbagai macam jurusan, perguruan tinggi dan lapangan pekerjaan dengan banyak membaca buku atau mencari di internet informasi terbaru mengenai karir.

Saran bagi penelitian selanjutnya dapat pula diteliti lebih lanjut mengenai intervensi career counseling dengan 
pendekatan career information-processing model pada jumlah partisipan yang lebih luas agar hasil penelitian dapat digeneralisasikan. Peneliti juga menyarankan agar pada penelitian selanjutnya dapat membagi partisi-pan dengan randomisasi kelompok kontrol dan kelompok eksperimen. Hal ini bertujuan untuk menguji keterandalan hasil penelitian dengan analisis statistik yang lebih kuat karena terdapat kelompok pembanding.

\section{Daftar Pustaka}

Austin, K.R., Dahl, D.A,. \& Wagner, D.B. (2010). The Role of Negative Career Thoughts and Sense of Coherence in Predicting Career Decision Status, Canadian Journal of Counseling, 44(1), 65-77.

Brown, Duane. (2012). Career Information, Career Counseling, and Career Development $\left(10^{\text {th }}\right.$ ed.), Boston: Chapel Hill.

Chason, K.A., Yowell, B.E., Sampson, Jr., Lenz, G.J., \& Reardon, C.R. (2013). Relationships among Career Thoughts, Career Interest, and Career Decision State, The Canadian Journal of Career Development, 12(1), 39-47.

Gati, I. \& Levin, N. (2014). Counseling for Decision-Making Difficulties: Measures and Methods, The Career Development Quarterly, 62, 98-113.

Henderson, K.M. (2009). The Effects of a Cognitive Information Processing Career Intervention on the Dysfuntional Career Thoughts, Locus of Control, and Career Decision SelfEfficacy of Underprepared College Students, Unpublished dissertation, Kansas State University.

Intani, F.S. \& Surjaningrum, E.R. (2010). Coping Strategy pada Mahasiswa Salah Jurusan, Jurnal Insan Fakultas Psikologi Universitas Airlangga Surabaya, 12(2).
Isaacson, L.E. \& Brown, D. (1997). Career Information, Career Counseling, and Career Development $\left(6^{\text {th }}\right.$ ed. $)$, Boston: Allyn \& Bacon.

Paivandy, L.S. (2009). The Validity of Cognitive Constructs in Cognitive Information Processing and Social Cognitive Career Theories, Unpublished dissertation, Florida State University.

Papalia, D.E., Olds, S.W., \& Feldman, R.D. (2007). Human Development (10 thed.), New York: McGraw Hill.

Patton, W. \& McMahon, M. (2014). Career Development and Systems Theory: Connecting Theory and Practice ( $3^{r d}$ ed.), Boston: Sense.

Peter, Creed, A.P., Wong, Y.O., \& Hood, M. (2009). Career Decision-Making, Career Barriers and Occupational Aspirations in Chinese Adolescents, International Journal Education Vocational Guidance, 9, 189-203.

Saam, Zulfan. (2013). Psikologi Konseling $\left(I^{s t} e d.\right)$, Jakarta: Rajawali.

Sampson, J.P., Peterson, G.W., Reardon, R.C., \& Lenz, J.G. (2000). Using Readiness Assesment to Improve Career Service: A Cognitive Information-Processing Approach, Journal ProQuest The Career Developmental Quarterly, 49(2), 146.

Santrock, J.W. (2001). Adolescene: Perkembangan remaja (edisi ke-6), Jakarta: Penerbit Erlangga.

(2011). Educational Psychology (5 $5^{\text {th }}$ ed.), New York: McGraw Hill.

Seniati, L., Yulianto, A., \& Setiadi, B.N. (2005). Psikologi Eksperimen, Jakarta: PT. Indeks.

Solso, R.L. (1991). Cognitive Psychology (3nd ed.), Boston: Allyn \& Bacon.

Stewart, A.C. \& Friedman, S. (1987). Child Development: Infancy through Adolescene, New York: John Wiley \& Sons. 
Strohm, A.D. (2008). The Impact of a Cognitive Information-Processing Intervention on Dysfunctional Career Thoughts and Vocational Identity in High School Students, Unpublished dissertation, Kansas State University.

Walgito. (2007). Pengantar Psikologi Umum, Yogyakarta: Andi offset.

Yowell, B.E., Kats, P.S., Reardon, C.R., \& Peterson, W.G. (2012). The Role of Negative Career Thinking and Career Problem-Solving Self-Efficacy in Career Exploration Behavior, The Professional Counselor, 2(2), 102114.
Yowell, B.E., Peterson, W.G., Reardon, C.R., Leierer, J.S., \& Reed, A.C. (2011). Relationship among Career and Life Stress, Negative Career Thoughts, and Career Decision State: A Cognitive Information Processing Perspective, The Career Development Quarterly, 59(4), 302-314.

Zunker, G.V. (2012). Career Counseling a Holistic Approach. Canada: Macmil. 